\title{
Preparation of Iron Nanoparticles by Selective Leaching Method
}

\author{
A. Michalcová ${ }^{a, *}$, D. Vojtěch ${ }^{a}$, T.F. Kubatík ${ }^{b}$, K. Stehlíková ${ }^{a}$, F. $_{\text {Brabec }}{ }^{a}$ \\ AND I. MAREK ${ }^{a}$ \\ ${ }^{a}$ Department of Metals and Corrosion Engineering, Institute of Chemical Technology, Prague, \\ Technicka 5, Prague 6, 166 28, Czech Republic \\ ${ }^{b}$ Institute of Plasma Physics AS CR, v.v.i., Za Slovankou 1782/3v, Prague 8, 182 00, Czech Republic
}

\begin{abstract}
Iron nanoparticles were prepared by selective leaching method. Initially the rapidly solidified AlFe11 alloy was prepared and consequently the aluminium matrix was dissolved from this alloy in $20 \% \mathrm{NaOH}$ solution. This process was carried out at 0 and $80^{\circ} \mathrm{C}$. At lower temperature, the iron nanoparticles covered by thin layer of $\mathrm{Fe}(\mathrm{OH})_{3}$ were successfully obtained. The size of formed nanoparticles was about $8 \mathrm{~nm}$ and the particles exhibited massive agglomeration. It is not limitation of the process, because the application of nanoparticles is as a precursor for production of bulk nanocrystalline materials (metals, alloys and metal matrix composites). At higher temperature, the selective leaching process failed and iron was oxidized to different hydroxides. Aluminium containing waste liquid from selective leaching was used for production of powder $\mathrm{Al}_{2} \mathrm{O}_{3}$. Initial alloys and products were characterized by X-ray diffraction, scanning electron microscopy, and high resolution transmission electron microscopy.
\end{abstract}

DOI: 10.12693/APhysPolA.128.640

PACS: 61.05.J-, 61.05.cp, 75.50.Bb, 81.40.-z, 81.07.Bc

\section{Introduction}

Nanocrystalline iron [1] and iron nanoparticles are very interesting material for their magnetic properties $[2,3]$ and catalytic ability [4]. The nanoparticles can be prepared by several ways such as reduction of ferrous ion by suitable reduction agent [3], flame spray pyrolysis [2] or selective leaching method.

The selective leaching technique lays in preparation of supersaturated solid solution of desired element in matrix metal - by convenient heat treatment or by rapid solidification of the binary alloy. Consequently, the matrix metal is selectively dissolved and metal nanoparticles from the other metal are formed. The size, shape and agglomeration of forming metallic nanoparticles are dependent on many factors such as reaction temperature, concentration of leaching solution, additives present in leaching solution.

In this study, aluminium matrix was used. The reason for this is amphoteric behaviour, which enables aluminium dissolution in sodium hydroxide without affecting the minor metal. Forming iron nanoparticles are in the state of passivity, which means that they form socalled core/shell structure. The core is composed of the metal, while the shell is formed by oxides and hydroxides.

Selective leaching method enables to produce relatively high amounts of nanopowder. For this reason it can be used for production of precursors for powder metallurgy.

\footnotetext{
${ }^{*}$ corresponding author; e-mail: michalca@vscht.cz
}

\section{Experimental}

The master alloy with compositions of $\mathrm{Al}-11 \mathrm{wt} \% \mathrm{Fe}$ (corresponds to 20 at.\% Fe) was prepared by melting of appropriate amount of pure metals in induction furnace followed by melt spinning process with circumferential speed of cooling wheel of $20 \mathrm{~m} / \mathrm{s}$. The rapidly solidified alloy was leached in $20 \%$ (wt) solution of $\mathrm{NaOH}$, following this reaction (1):

$$
\begin{array}{r}
2.5 \mathrm{AlFe}_{20}+2 \mathrm{NaOH}+6 \mathrm{H}_{2} \mathrm{O} \rightarrow \\
2 \mathrm{Na}\left[\mathrm{Al}(\mathrm{OH})_{4}\right]+3 \mathrm{H}_{2}+0.5 \mathrm{Fe} .
\end{array}
$$

The iron nanoparticles were prepared by selective leaching at two different temperatures: 0 and $80^{\circ} \mathrm{C}$. Leaching was performed using magnetic stirring and heating device and the end of the process was detected visually when no gas bubbles were released.

The $\mathrm{CO}_{2}$ gas was injected into the waste liquid from selective leaching of aluminium matrix, which leads to precipitation of $\mathrm{Al}(\mathrm{OH})_{3}$ according to reaction (2). The $\mathrm{Al}(\mathrm{OH})_{3}$ was consequently annealed at $900^{\circ} \mathrm{C}$ and $\mathrm{Al}_{2} \mathrm{O}_{3}$ was obtained by the following reaction (3):

$$
\begin{aligned}
& 2 \mathrm{Na}\left[\mathrm{Al}(\mathrm{OH})_{4}\right]+\mathrm{CO}_{2} \rightarrow \\
& \quad \mathrm{Na}_{2} \mathrm{CO}_{3}+2 \mathrm{Al}(\mathrm{OH})_{3}+\mathrm{H}_{2} \mathrm{O}, \\
& 2 \mathrm{Al}(\mathrm{OH})_{3} \rightarrow \mathrm{Al}_{2} \mathrm{O}_{3}+3 \mathrm{H}_{2} \mathrm{O} .
\end{aligned}
$$

Phase composition of initial materials and products was determined by X-ray diffraction (PAN analytical X'Pert PRO \& High Score Plus, $\mathrm{Cu}$ anode). The structure of $\mathrm{Al}_{2} \mathrm{O}_{3}$ particles was observed by scanning electron microscope TESCAN VEGA 3 LMU equipped by EDS detector (Oxford Instruments). Structure of prepared nanoparticles was studied by transmission electron microscope JEOL JEM 3010 operated at $300 \mathrm{kV}$ $\left(\mathrm{LaB}_{6}\right.$ cathode, point resolution $\left.=1.7 \AA\right)$. Selected area 
electron diffraction (SAED) patterns were evaluated using DiffTools Script Package for Digital Micrograph (version 3.8) and Process Diffraction software package.

\section{Results and discussion}

The rapidly solidified $\mathrm{AlFe} 11$ alloy consists of fcc-Al (saturated with $\mathrm{Fe}$ ) and $\mathrm{Al}_{13} \mathrm{Fe}_{4}$ intermetallic phase, as shown in Fig. 1. Rapid solidification under the conditions described in experiment does not lead to formation of metastable phases but causes formation of finer structure which is more convenient for selective leaching process. Selective leaching at $0^{\circ} \mathrm{C}$ leads to dissolution of fcc-Al matrix and also to dissolution of $\mathrm{Al}$ from $\mathrm{Al}_{13} \mathrm{Fe}_{4}$ phase. As a product, the $\alpha$-Fe nanoparticles are formed with

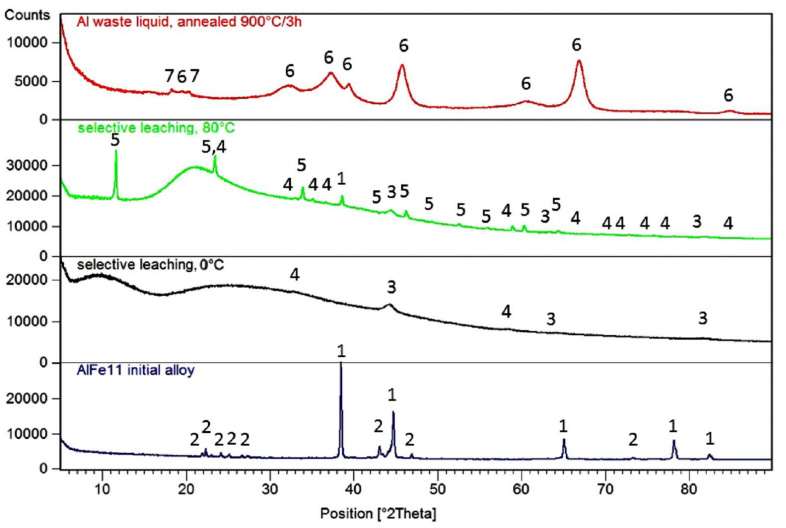

Fig. 1. XRD patterns of initial AlFe11 alloy, product of selective leaching prepared at 0 and $80^{\circ} \mathrm{C}$ and $\mathrm{Al}_{2} \mathrm{O}_{3}$ prepared from waste Al-containing liquids ( 1 - fcc-Al, $2-\mathrm{Al}_{13} \mathrm{Fe}_{4}, 3-\alpha-\mathrm{Fe}, 4-\mathrm{Fe}(\mathrm{OH})_{3}, 5-\mathrm{FeO}(\mathrm{OH})$, $\left.6-\mathrm{Al}_{2} \mathrm{O}_{3}, 7-\mathrm{Al}(\mathrm{OH})_{3}\right)$.

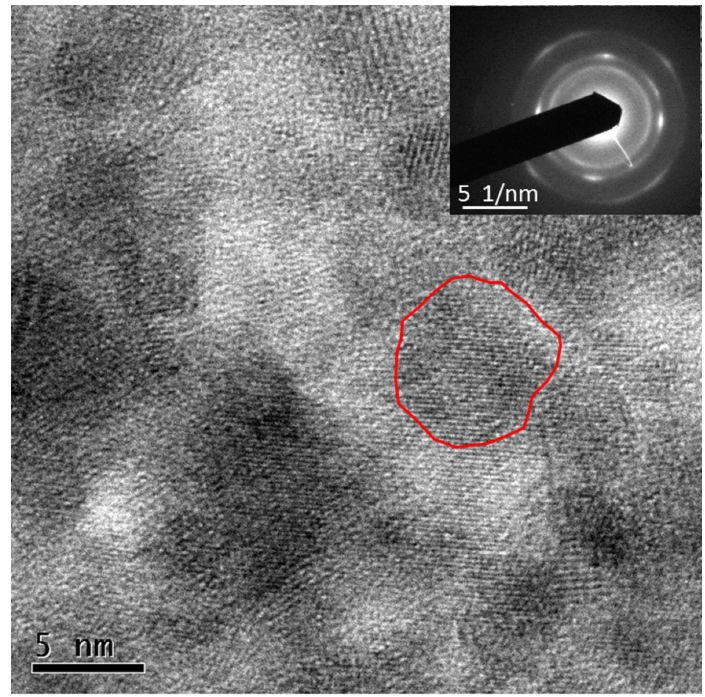

Fig. 2. HRTEM image of nanoparticles prepared by selective leaching process at $0^{\circ} \mathrm{C}$, in right-top corner corresponding SAED pattern. One iron nanoparticle is emphasized by red line.

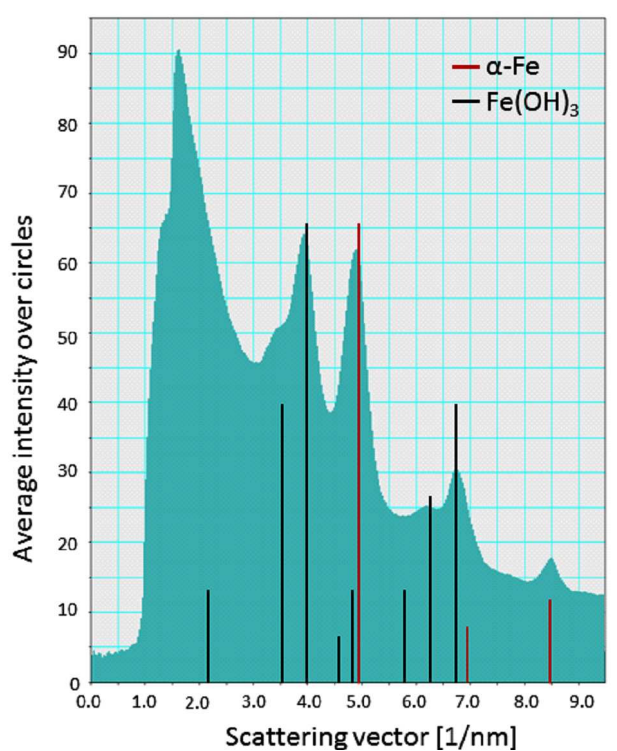

Fig. 3. Integrated SAED pattern from Fig. 2.

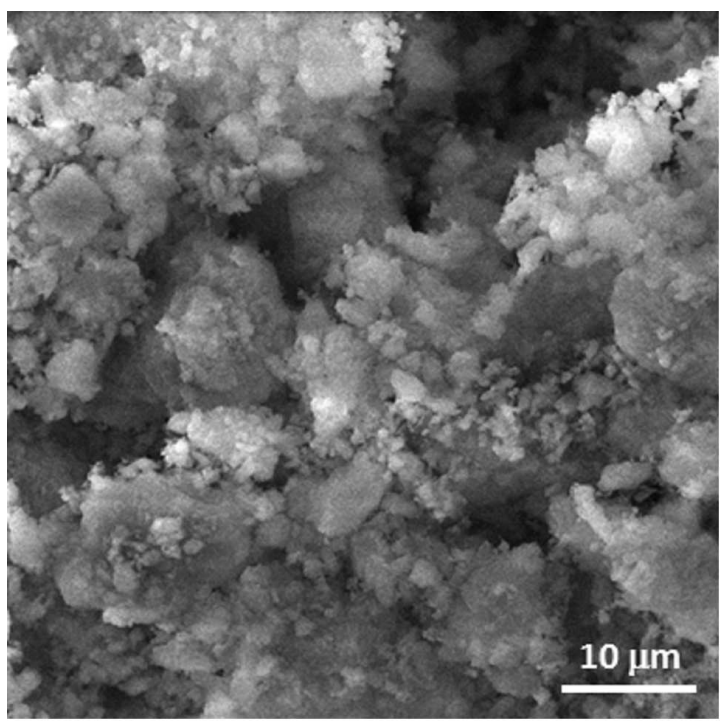

Fig. 4. Structure of $\mathrm{Al}_{2} \mathrm{O}_{3}$ obtained from waste liquid (SEM).

small amount of $\mathrm{Fe}(\mathrm{OH})_{3}$. The size of $\mathrm{Fe}$ nanoparticles - determined by the Scherrer calculator from broadening of X-ray diffraction (XRD) peak corresponding to (110) plane - is $8 \mathrm{~nm}$. This value is in good agreement with the high resolution transmission microscopy (HRTEM) observations, see Fig. 2. It was observed that the nanoparticles are agglomerated in submicrometer clusters. The SAED pattern in the right up corner of Fig. 2 shows diffuse but distinguishable reflections, indicating that the phase is nanocrystalline. The interpretation of SAED pattern is given in Fig. 3 and documents presence of $\alpha$-Fe and $\mathrm{Fe}(\mathrm{OH})_{3}$. The higher amount of $\mathrm{Fe}(\mathrm{OH})_{3}$ detected by SAED than by XRD can be explained by different sample preparation. The TEM sample was dried before observation, which leads to increase 
of particles oxidation. The XRD pattern was measured in protective isopropanol surrounding.

The increase of leaching temperature causes change in phase composition of product, as Fig. 1 documents. After leaching at $80^{\circ} \mathrm{C}$ the product contains high amount of $\mathrm{Fe}(\mathrm{OH})_{3}$ and $\mathrm{FeO}(\mathrm{OH})$. These corrosion products even passivize aluminium matrix, which is shown by presence of peaks of residual $\mathrm{Al}$ in XRD pattern. These results indicate that increase of temperature is not suitable for production of Fe nanoparticles by selective leaching process.

The waste liquid from selective leaching of aluminium matrix was treated to extract useful product. $\mathrm{Al}(\mathrm{OH})_{3}$ is precipitated for the waste liquid by changing of $\mathrm{pH}$ value (by $\mathrm{CO}_{2}$ injection). Consequently it is annealed at $900{ }^{\circ} \mathrm{C}$ for $3 \mathrm{~h}$, which leads to formation of almost pure $\mathrm{Al}_{2} \mathrm{O}_{3}$, as shown in Fig. 1. The structure of obtained $\mathrm{Al}_{2} \mathrm{O}_{3}$ powder is shown in Fig. 4. This $\mathrm{Al}_{2} \mathrm{O}_{3}$ powder can be used e.g. as reinforcement for composite materials [5].

\section{Conclusion}

It was proven in this study that selective leaching process of Fe nanoparticles from AlFe11 alloy leads to formation of $\mathrm{Fe} / \mathrm{Fe}(\mathrm{OH})_{3}$ nanoparticles agglomerated in clusters. Lower temperature of the process seems to be more suitable, because increase of temperature from $0^{\circ} \mathrm{C}$ to $80^{\circ} \mathrm{C}$ causes significant oxidation of product. The size of Fe nanoparticles prepared at $0^{\circ} \mathrm{C}$ is $8 \mathrm{~nm}$. Waste liquid from selective leaching process can be successfully turned into $\mathrm{Al}_{2} \mathrm{O}_{3}$ powder.

\section{Acknowledgments}

The authors thank to Tristan P. Harzer for his help with data treatment. This research was financially supported by Czech Science Foundation, project No. P108/12/G043.

\section{References}

[1] B. David, O. Schneeweiss, N. Pizúrová, A. Rek, V. Kudrle, O. Jašek, Acta Phys. Pol. A 126, 94 (2014).

[2] Y. Li, Y. Hu, G. Huang, C. Li, Particuology 11, 460 (2013).

[3] C.Y. Wang, Z.Y. Chen, B. Cheng, Y.R. Zhu, H.J. Liu, Mater. Sci. Eng. B-Solid 60, 223 (1999).

[4] D.A. Kim, S.W. Han, H.S. Yoon, Y.D. Kim, J. Ind. Eng. Chem. 23, 67 (2015).

[5] P. Novák, D. Šotka, M. Novák, A. Michalcová, J. Šerák, D. Vojtěch, Powder Metall. 54, 308 (2011). 